\title{
ERRATUM
}

\section{EFFECTS OF ONCE-DAILY VERSUS TWICE DAILY DOSING OF CALCIUM FRUCTOBORATE ON KNEE DISCOMFORT. A 90 DAY, DOUBLE-BLIND, PLACEBO CONTROLLED RANDOMIZED CLINICAL STUDY}

\author{
Z. Pietrzkowski ${ }^{1}$, A. Roldán Mercado-Sesma ${ }^{3}$, R. Argumedo ${ }^{1}$, M. Cervantes $^{1}$, B. Nemzer ${ }^{2}$, T. Reyes-Izquierdo
}

Regarding the above-mentioned article, it has come to the journal's attention that the authors have not declared in the Disclosure Statement section of the manuscript they were employed by VDF FutureCeuticals, Inc. Therefore, instead of:

Disclosure Statement: The present study was funded by Futureceuticals, Inc. (Momence IL, USA). All authors declare that they have no conflicts of interest. No competing financial interests exist.

The correct Disclosure Statement is: The present study was funded by VDF FutureCeuticals, Inc (Momence IL, USA). At the time of submission, Z. Pietrzkowski, R. Argumedo, M. Cervantes, B. Nemzer and T. Reyes-Izquierdo were employed by VDF FutureCeuticals, Inc.

Furthermore, following ICMJE recommendations, JARLife requested to the authors to retrospectively register the clinical trial reported in this article in a publicly accessible registry

1. Bioresearch Lab, VDF Futureceuticals Inc.; 23 Peters Canyon Rd, Irvine, CA USA 92606; 2. VDF Futureceuticals Inc.; 2692 N. State Rt. 1-17., Momence, IL, USA 60954; 3. Departamento de Salud-Enfermedad, Centro Universitario de Tonalá, Universidad de Guadalajara. Av. Nuevo Periférico No. 555 Ejido San José Tatepozco, C.P. 45425, Tonalá Jalisco, México. 